\title{
PERFORMANCE OF SQUARE PILE GROUPSUBJECTED TO INCLINED LOADS USING MIDAS 3D
}

\author{
S. S. Pusadkar ${ }^{1}$, M. A. Kapse ${ }^{2}$ \\ ${ }^{1}$ Associate Professor, Civil Engineering Department, Government College of Engineering, M. S., India, 444604 \\ ss_pusadkar@yaho.co.in \\ ${ }^{2}$ P.G.Scholar, Civil Engineering Department, Government College of Engineering, M. S., India, 444604 \\ kapse34@gmail.com
}

\begin{abstract}
The inclined load on pile may be inclined with vertical plane or horizontal plane. The angle of inclination with a particular plane influences the stresses and settlement of piles in groups. The stresses and settlement of piles from a pile group subjected to inclined load influences the performance of pile group. The present study investigated the effect of inclined loads inclined in vertical and horizontal plane, on the performance of square pile group. The finite element software MIDAS $3 D$ was used for the analysis. The inclined load considered for study was with inclination in vertical plane from 00 to 300 and in horizontal plane from 00 to 450. The study also includes the effect of inclined load on square pile group with varying spacing and length of piles. The settlement of each pile was measured and illustrated. It was observed that the settlement of pile depends upon the location of pile and the loading direction.
\end{abstract}

Keywords: Pile Foundation, Inclined Load, Load Carrying Capacity, Load Direction.

\section{INTRODUCTION}

The pile foundation of various structures is subjected to inclined load which may be in compression or tensile nature. These includes, towers for electric transmission, mobile towers, wind turbine towers, offshore structures etc. The piles in foundation may be undergone different stress and moment condition depending upon the nature and direction of load. The settlement and load capacity of pile also affected due to loading condition and direction.

Inclined loads acting on piles cause failure of pile groups and soil around the piles. To counteract these failures proper study of distribution of forces and moments on piles is essential. The proper understanding of interaction effects of pile and soil under inclined load is required to be studied. The present work aims on studying the performance of pile groups under inclined loads using MIDAS 3D. This work will put some insight into the behavior of pile group under inclined load.

The work on lateral behavior of pile groups in layered soils shows that interaction among the piles grows with the increase in lateral loading [1].

The study concluded that lateral capacity of piles in $3 \times 3$ groups with 3D spacing decreases by $40 \%$ and the maximum bending moment in piles increases by $20 \%$ in comparison to the single pile. The deflection of pile group was about two times higher than that of the single pile [2]. The settlement and the lateral deflection of pile under inclined load depend on both axial and normal components of the inclined load applied [3].

$\mathrm{Su}$ and Zhou concluded that the loading direction affects distribution of force among piles in the pile group and the bending responses along the piles, and the total lateral resistance of the pile group [4].

The literature shows a few work is carried out on pile group subjected to inclined load with variation in inclination in vertical plane and horizontal plane. Hence, detailed investigation is carried out using MIDAS 3D.

\section{ANALYSIS BY MIDAS 3D}

The geometry of soil model adopted in the analysis using MIDAS 3D was based on stress induction in the soil model and boundary effect up to which the stresses are diminishing. The size of soil model adopted for the analysis is $10 \mathrm{~B} \times 10 \mathrm{~B}$ and depth is equal to $\mathrm{L}+4 \mathrm{~B}$ where $\mathrm{L}$ is embedded length of pile and B is width of pile cap. The detail of the analytical model used in analysis is shown in Fig 1.

For analysis a pile group of 4 piles was considered. Fig. 2 shows the square pile group with $3 \mathrm{D}$ spacing between the piles and all the dimensions. Fig. 3 indicates the geometry modeling of square pile group in MIDAS 3D for analysis. For each pile group configurations the separate model was prepared and the analyses were carried out for each combination of inclined load. 


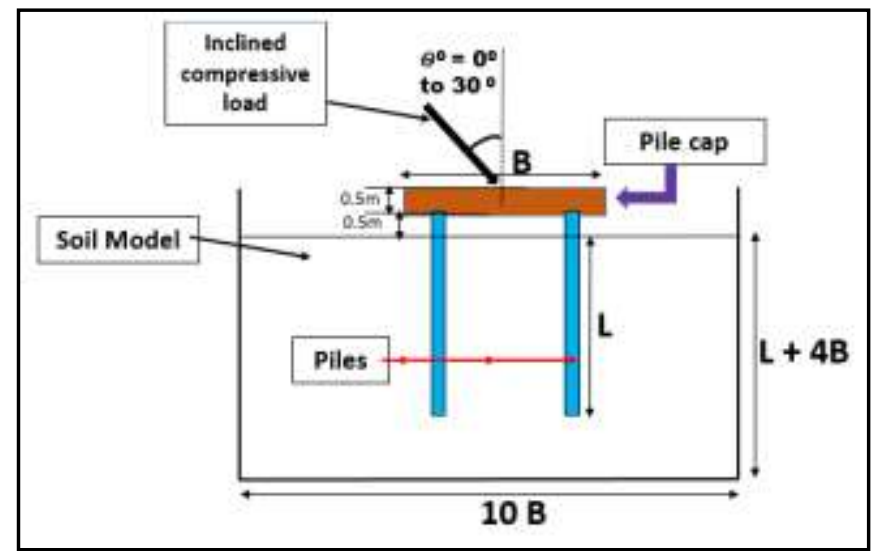

Fig -1: Analytical Model under Consideration

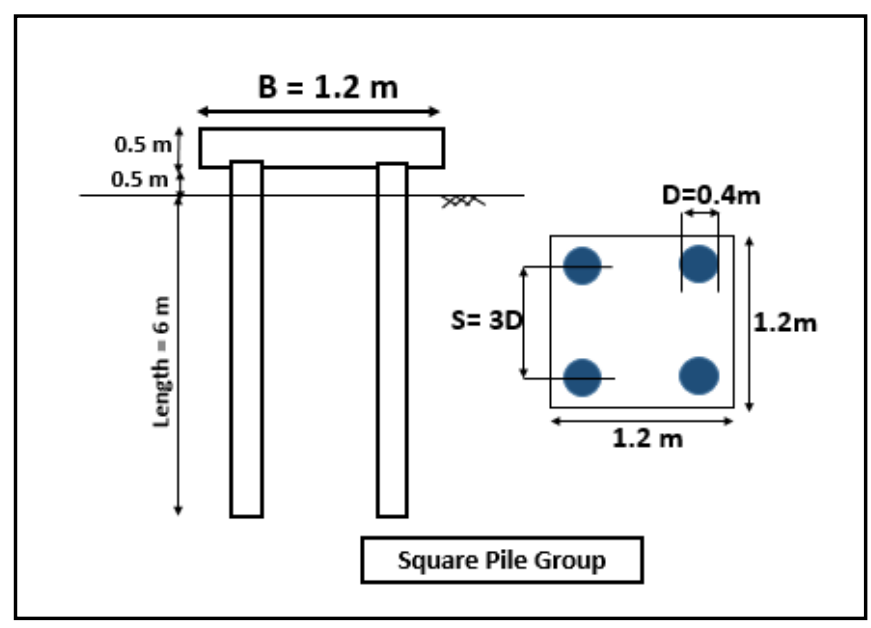

Fig -2: 2 × 2 Square Pile Group with 3D Spacing

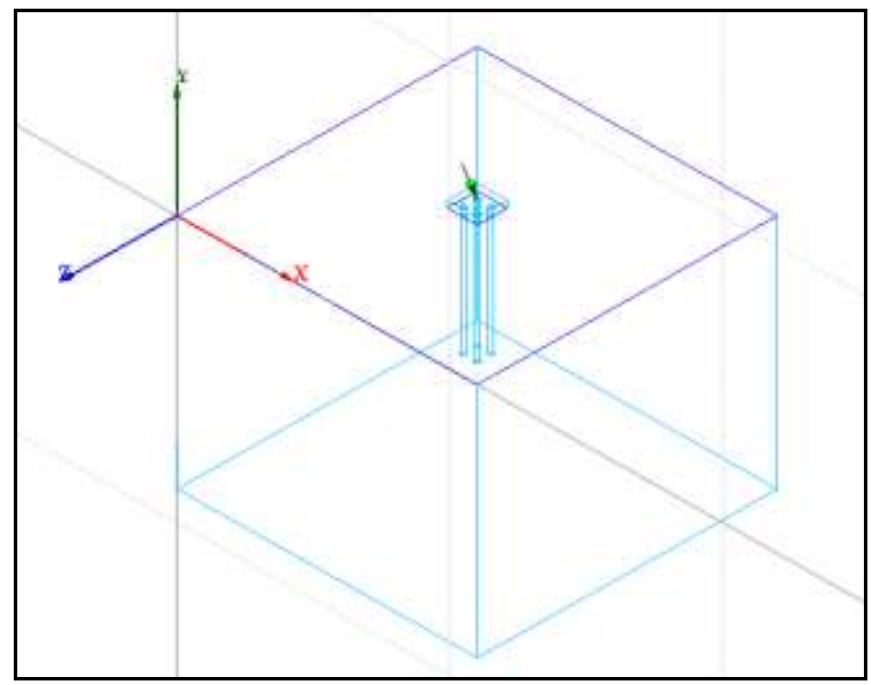

Fig -3: Geometry modeling of square pile group in MIDAS $3 \mathrm{D}$

\section{MATERIAL PROPERTIES}

The pile and pile cap was considered as beam structure made of concrete and assumed to be a linear elastic material. The analysis was carried out on sandy strata. The soil model was considered as Mohr-Coulomb model. Table 1 and Table 2 shows pile properties and soil properties considered for analyzing pile group in MIDAS 3D software.
Table 1: Pile and Pile Cap Properties

\begin{tabular}{|l|l|l|}
\hline $\begin{array}{l}\text { Sr. } \\
\text { No }\end{array}$ & Parameter & Values \\
\hline 1 & Young's modulus E $\left(\mathrm{kN} / \mathrm{m}^{2}\right)$ & $2 \times 10^{8}$ \\
\hline 2 & Dry unit weight $\left(\mathrm{kN} / \mathrm{m}^{3}\right)$ & 24 \\
\hline 3 & Poisson's ratio $v$ & 0.18 \\
\hline 4 & Material model & Elastic \\
\hline
\end{tabular}

Table -2: Name of the Table

\begin{tabular}{|l|l|l|}
\hline $\begin{array}{l}\text { Sr. } \\
\text { No }\end{array}$ & Properties of Soil & Sand \\
\hline 1 & Unsaturated unit weight $\left(\mathrm{kN} / \mathrm{m}^{3}\right)$ & 20 \\
\hline 2 & Dry unit weight $\left(\mathrm{kN} / \mathrm{m}^{3}\right)$ & 19 \\
\hline 3 & Cohesion c $\left(\mathrm{kN} / \mathrm{m}^{2}\right)$ & 1 \\
\hline 4 & Poisson's ratio $v$ & 0.3 \\
\hline 5 & Young's modulus E $\left(\mathrm{kN} / \mathrm{m}^{2}\right)$ & 22300 \\
\hline 6 & Angle of internal friction $\left(\phi^{0}\right)$ & 35 \\
\hline 7 & Material model & Mohr Coulomb \\
\hline 8 & Type of material behavior & Drained \\
\hline
\end{tabular}

\section{PILE CONFIGURATION AND TEST SCHEME}

MIDAS 3D was used to analyze the different configurations of length and spacing on square pile group with different loading directions in vertical plane and horizontal plane. The parameters studied are given in Table 3 . The pile group was loaded up to a vertical settlement of $10 \%$ of pile diameter. The load corresponds to this settlement was taken as load carrying capacity of pile group. If any pile in pile group attains the specified amount of settlement for the given inclined load then that load was considered as load carrying capacity of the pile group. All the load combinations were applied in the third quadrant of the pile cap.

Table 3: Different Parameters for Analysis

\begin{tabular}{|c|c|c|}
\hline $\begin{array}{l}\text { Sr. } \\
\text { No. }\end{array}$ & Parameter & Value \\
\hline 1 & Numbers of piles in a group & 4 \\
\hline 2 & Spacing of piles & $2.5 \mathrm{D}, 3 \mathrm{D}, 4 \mathrm{D}$ \\
\hline 3 & Diameter of pile & $400 \mathrm{~mm}$ \\
\hline 4 & Length of pile & $6,9,12 \mathrm{~m}$ \\
\hline 5 & Pattern of pile group & Square \\
\hline 6 & $\begin{array}{l}\text { Load inclination with vertical } \\
\text { plane }(\theta)\end{array}$ & $0^{0}, 10^{0}, 20^{0}, 30^{0}$ \\
\hline 7 & $\begin{array}{l}\text { Load inclination in horizontal } \\
\text { plane }(\delta)\end{array}$ & $0^{0}, 15^{0}, 30^{0}, 45^{0}$ \\
\hline 9 & Software used & MIDAS 3D \\
\hline
\end{tabular}




\section{RESULTS AND DISCUSSION}

The analysis was carried out in MIDAS 3D for square pile group having different configurations and load inclination. For the typical case of square pile group the results obtained in MIDAS 3D is shown in Fig. 4 and Fig. 5. It shows the result in terms of load settlement curve for vertical load on 2 x 2 square pile group. The load carrying capacity was computed corresponding to a settlement of $10 \%$ diameter of the pile.

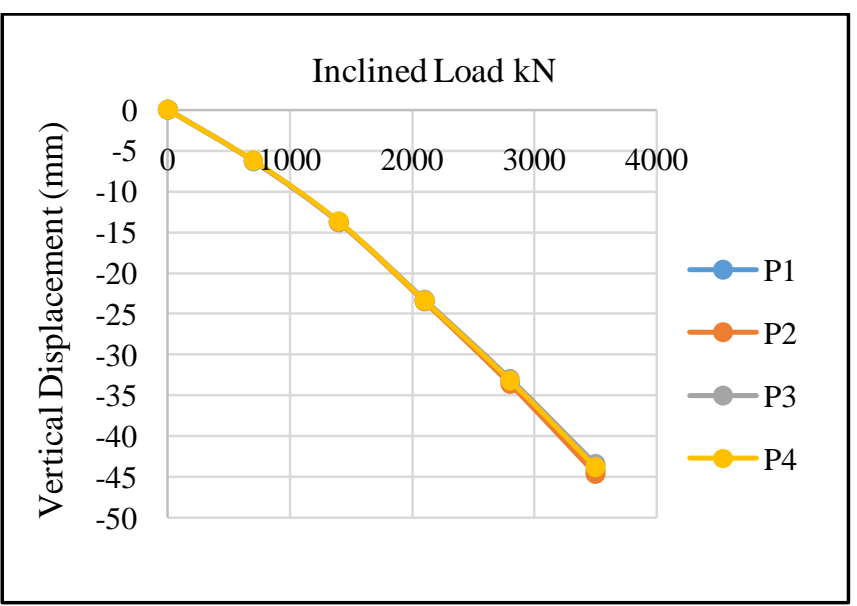

Fig -4: Load Displacement Curve of Square Pile Group with vertical laod

The inclination of load in vertical plane and horizontal plane was changed and the load displacement diagram was drawn. The vertical movements of each pile head in a square pile group were plotted against the applied inclined load. Fig. 4 indicates load displacement curve for pile group subjected to inclined load of $20^{\circ}$ inclinations with vertical $(\theta)$ and varying inclinations in horizontal plane $(\delta)$. It reveals that as the load inclination with vertical plane changes, the front piles undergo more settlement than rear piles. The increase in the load inclination in horizontal plane, the front row pile $\mathrm{P} 2$ experiencing more settlement than $\mathrm{P} 1$. The increase in load inclination in horizontal plane results in decrease in the load capacity of the pile group.

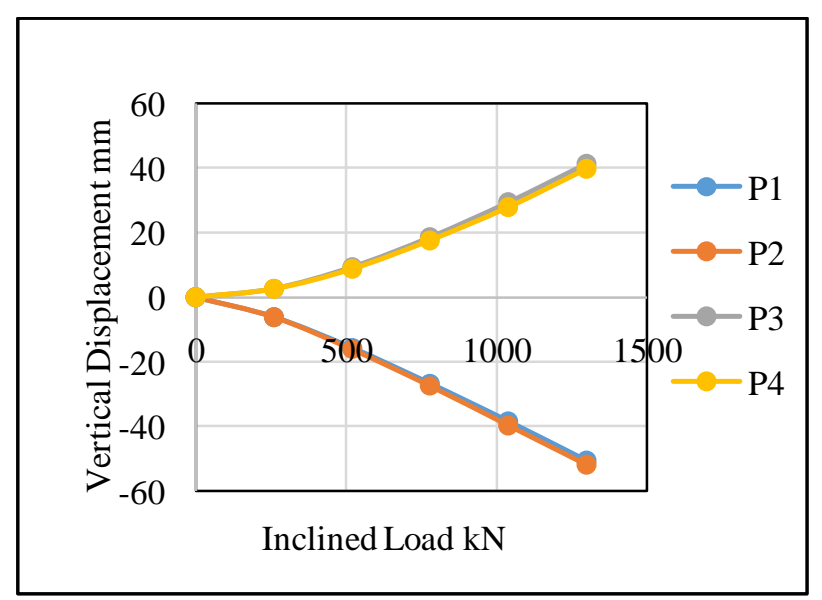

(a) $\mathrm{S}=2.5 \mathrm{D}, \mathrm{L}=6 \mathrm{~m}, \theta=200, \delta=00$

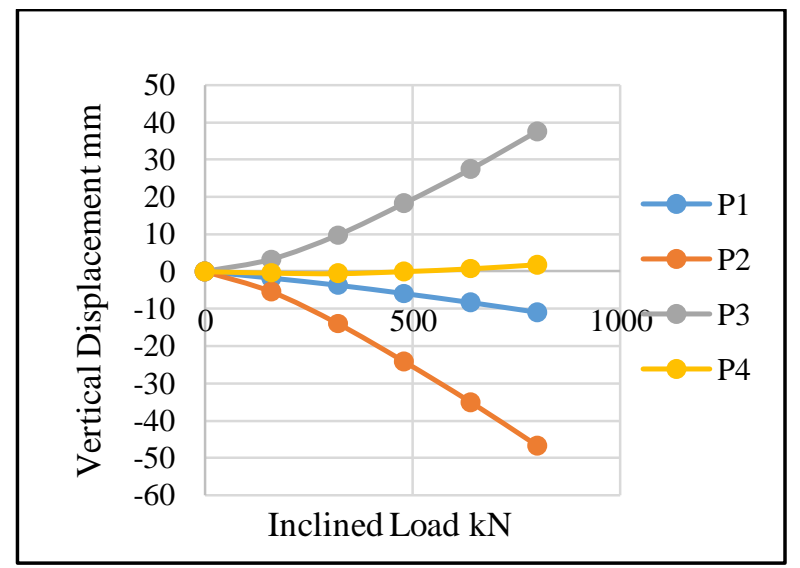

(b) $\mathrm{S}=2.5 \mathrm{D}, \mathrm{L}=6 \mathrm{~m}, \theta=20^{0}, \delta=15^{0}$

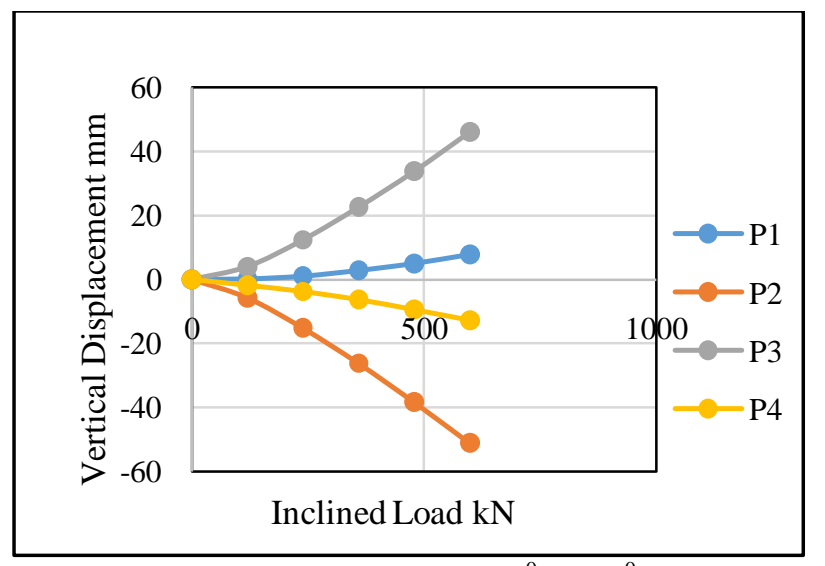

(c) $\mathrm{S}=2.5 \mathrm{D}, \mathrm{L}=6 \mathrm{~m}, \theta=20^{\circ}, \delta=30^{\circ}$

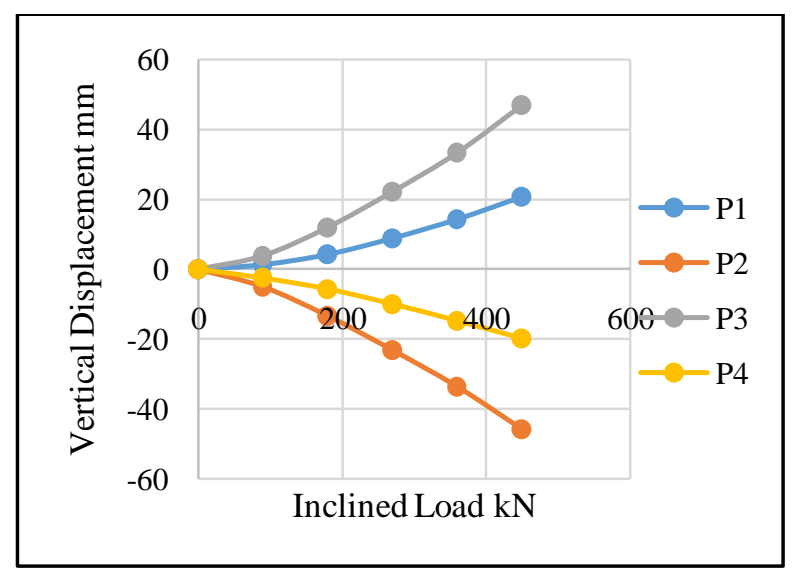

(d) $\mathrm{S}=2.5 \mathrm{D}, \mathrm{L}=6 \mathrm{~m}, \theta=20^{\circ}, \delta=45^{0}$

Figure 5: Load Displacement Curves for Square Pile Group with inclined load

\subsection{Effect of Load Inclination}

Fig. 6 shows the displacement of pile P2 in square pile group for different load inclinations and combinations of loads according to the parameters adopted in the study. After application of the particular set of inclined load to the square pile group, pile P2 first attains the settlement of $10 \%$ of pile diameter for all the cases studied. It reveals that movement of pile for a particular settlement is totally depend upon the direction of loading and quadrant in which the load is acting. 


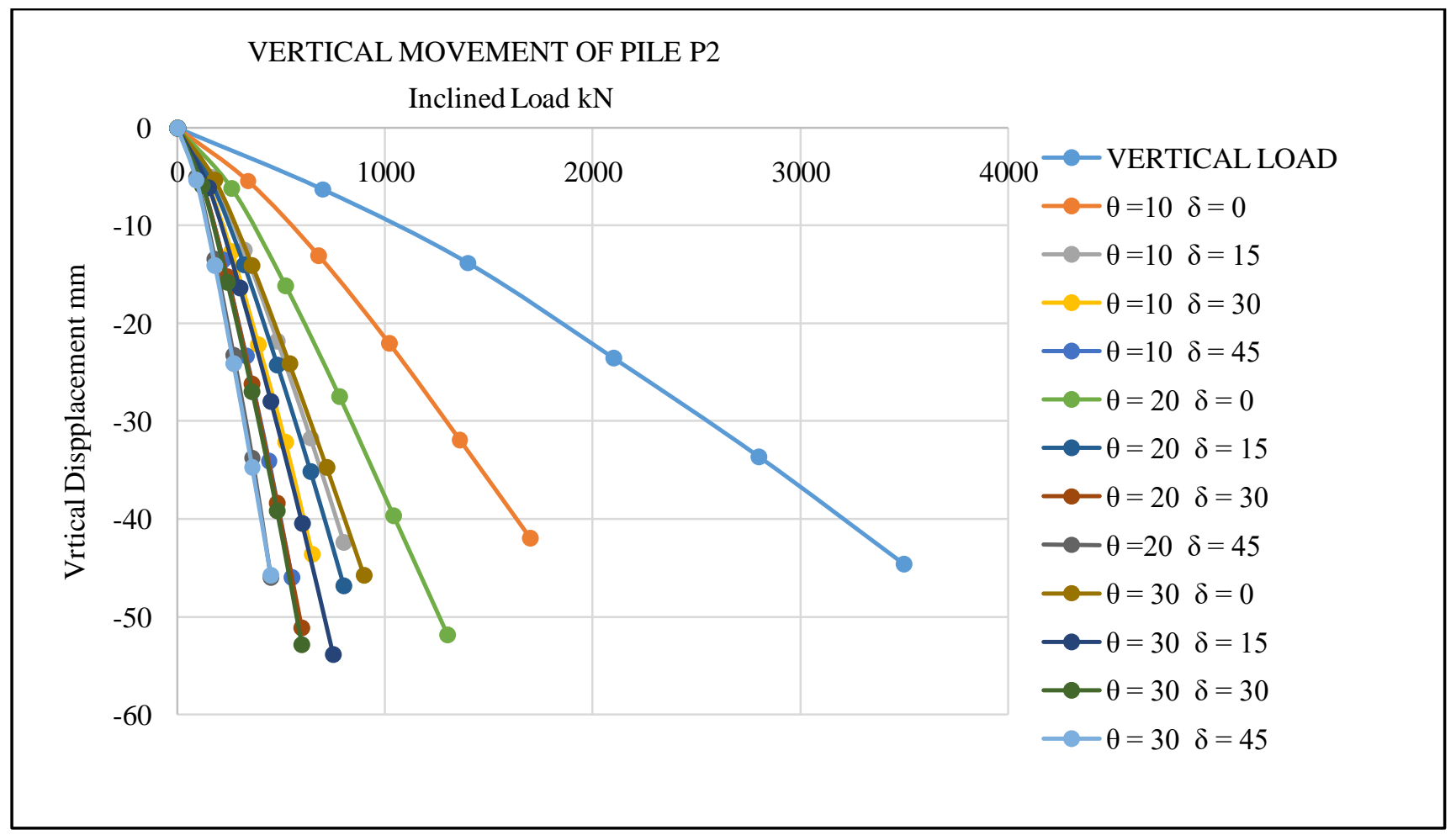

Fig -6: Load Displacement Curve of Pile P2

\subsection{Effect of Load Inclination}

Table 4 gave the load carrying capacities of square pile group for different configuration of spacing between the piles, length, and diameter of piles. It can be seen that if vertical load is inclined in vertical plane by $10^{\circ}$, the load carrying capacity of pile group is decreases approximately up to $50 \%$. Similarly, if load inclination in horizontal plane is changed to $15^{\circ}$, further load carrying capacity is decreased by $50 \%$. Thus, load inclination in vertical plane and horizontal plane greatly influence the load carrying capacity of pile group. The load carrying capacity of pile group decreases as the load inclination on a pile group increases.

Table 4: Load Carrying Capacities for Square Pile Group (kN)

\begin{tabular}{|c|c|c|c|c|c|c|c|c|c|c|c|}
\hline \multirow{2}{*}{\multicolumn{3}{|c|}{$\begin{array}{l}\text { LOADING } \\
\text { CONDITIONS }\end{array}$}} & \multicolumn{3}{|c|}{ Length of pile $=6 \mathrm{~m}$} & \multicolumn{3}{|c|}{ Length of pile $=9 \mathrm{~m}$} & \multicolumn{3}{|c|}{ Length of pile $=12 \mathrm{~m}$} \\
\hline & & & $S=2.5 \mathrm{D}$ & $S=3 D$ & $S=4 D$ & $\mathrm{~S}=\mathbf{2 . 5 \mathrm { D }}$ & $\mathbf{S}=\mathbf{3 D}$ & $S=4 D$ & $\mathrm{~S}=\mathbf{2 . 5 \mathrm { D }}$ & $S=3 D$ & $S=4 D$ \\
\hline \multicolumn{3}{|c|}{$\begin{array}{c}\text { VERTICAL } \\
\text { LOAD }\end{array}$} & 3250 & 3500 & 4950 & 3500 & 4000 & 5000 & 3750 & 4200 & 5600 \\
\hline \multirow{4}{*}{$\begin{array}{l}10^{0} \\
\text { ELE }\end{array}$} & \multirow{4}{*}{$\begin{array}{c}\mathbf{P} \\
\mathbf{L} \\
\mathbf{A N}\end{array}$} & $\mathbf{0}^{0}$ & 1600 & 1850 & 2750 & 1500 & 1750 & 2500 & 1360 & 1600 & 2250 \\
\hline & & $15^{0}$ & 760 & 1050 & 1700 & 750 & 900 & 1400 & 660 & 760 & 1250 \\
\hline & & $30^{0}$ & 610 & 720 & 1200 & 480 & 625 & 925 & 430 & 500 & 850 \\
\hline & & $45^{0}$ & 500 & 580 & 1000 & 380 & 500 & 750 & 340 & 400 & 750 \\
\hline \multirow{4}{*}{$\begin{array}{l}20^{0} \\
\text { ELE }\end{array}$} & \multirow{4}{*}{$\begin{array}{c}\mathbf{P} \\
\mathbf{L} \\
\mathbf{A N}\end{array}$} & $\mathbf{0}^{0}$ & 1050 & 1200 & 1720 & 960 & 1050 & 1620 & 820 & 930 & 1400 \\
\hline & & $15^{0}$ & 700 & 850 & 1350 & 600 & 730 & 1100 & 510 & 600 & 970 \\
\hline & & $30^{0}$ & 500 & 680 & 1075 & 400 & 540 & 820 & 380 & 470 & 725 \\
\hline & & $45^{0}$ & 410 & 540 & 900 & 360 & 450 & 700 & 310 & 360 & 600 \\
\hline \multirow{4}{*}{$\begin{array}{l}3^{0} \\
\text { ELE }\end{array}$} & \multirow{4}{*}{$\begin{array}{c}\mathbf{P} \\
\mathbf{L} \\
\mathbf{A N}\end{array}$} & $\mathbf{0}^{0}$ & 800 & 930 & 1450 & 720 & 780 & 1250 & 600 & 680 & 1050 \\
\hline & & $15^{0}$ & 600 & 700 & 1150 & 500 & 600 & 900 & 430 & 500 & 800 \\
\hline & & $30^{0}$ & 490 & 580 & 950 & 400 & 480 & 750 & 340 & 400 & 650 \\
\hline & & $45^{0}$ & 400 & 490 & 850 & 340 & 425 & 650 & 290 & 350 & 560 \\
\hline
\end{tabular}


Fig.7 indicates the variation of load carrying capacities with respect to the load inclinations in vertical plane (elevation) and in horizontal plane (plan) for a square pile group having spacing $=2.5 \mathrm{D}$, length $=6 \mathrm{~m}$ and diameter $=400 \mathrm{~mm}$. The load inclination in plan and the load inclination in elevation results in reduction in the load carrying capacity significantly. The decrease in load carrying capacity after $10^{\circ}$ inclination in vertical plan and $15^{\circ}$ in horizontal plan is not seen to the great extent.

\subsection{Effect of Spacing Between The Piles}

Fig. 8 indicates the variation of load carrying capacities with spacing between the piles under consideration for different loading conditions. It shows that as the spacing between piles increases in a pile group, load carrying capacity of square pile group is increasing.

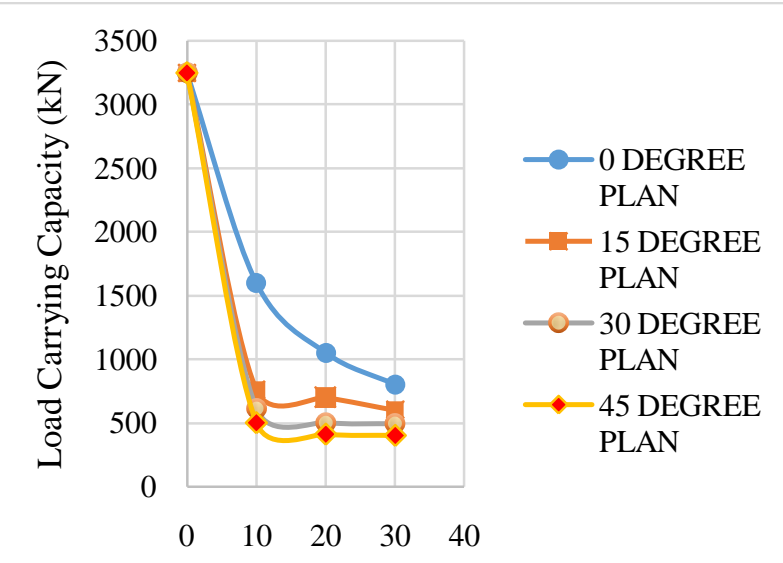

Inclination of Load in Elevation $\left(\theta^{0}\right)$

Fig -7: Load Carrying Capacity of Pile Group

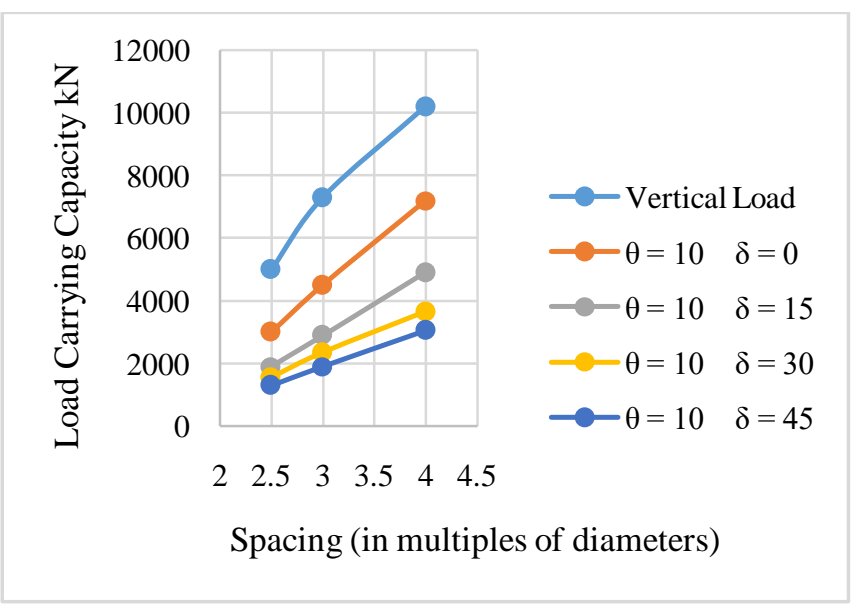

Fig -8:Effect of Spacing between the Piles on Load Carrying Capacity

\subsection{Effect of Length Of Piles}

Fig. 9 shows that when pile group is subjected to vertical load, an increase in the length of pile increases the load carrying capacity. But as load inclination increases, the load carrying capacity decreases.

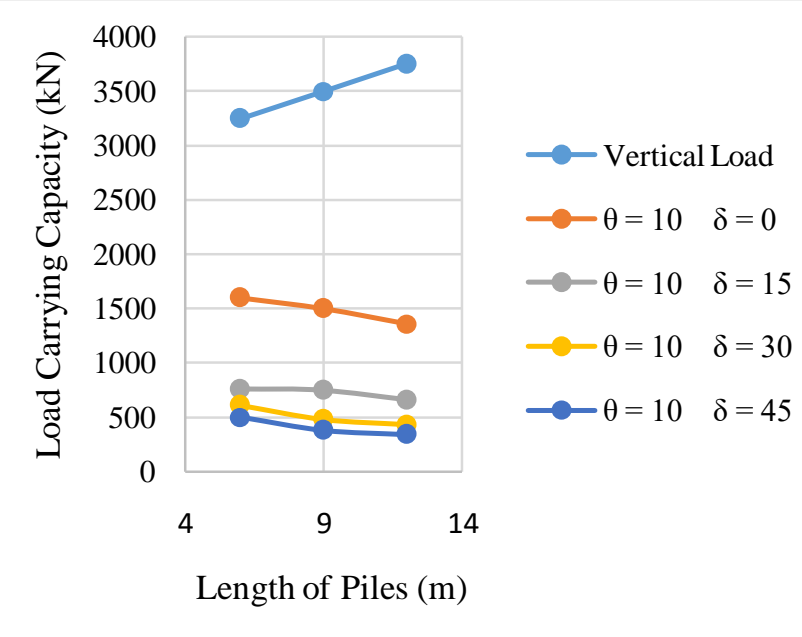

Fig -9: Effect of Length of Piles on Load Carrying Capacity

\section{CONCLUSIONS}

The square pile groups with different configurations of load inclination, length and spacing were investigated using MIDAS 3D. The study reveals the effect of loading direction. The results obtained conclude that:

1. The direction of load inclination on horizontal and vertical planes has a significant effect on the pile groups.

2. As the load inclination with vertical plane increases to $10^{0}$, the load carrying capacity of pile group decreases approximately by $50 \%$.

3. The load inclination more than $10^{\circ}$ does not influence pile capacity greatly after $10^{\circ} \mathrm{load}$ inclination.

4. For the $2 \times 2$ square pile group the front row piles experience more vertical settlement than rear row piles.

5. The load carrying capacity of pile increases with spacing of piles increases in pile group.

6. The load carrying capacity of pile group subjected to inclined load decreases as the length of pile increases.

\section{REFERENCES}

[1]. Ashour, M., Pilling, P., and Norris, G. (2004), "Lateral Behavior of Pile Groups in Layered Soils." Journal of Geotechnical and Geoenvironmental Engineering., Vol. 130 No. 6, pp. 580-592.

[2]. Chandrasekaran, S. S., Boominathan, A., and Dodagoudar, G. R. (2010), "Group Interaction Effects on Laterally Loaded Piles in Clay." Journal of Geotechnical and Geoenvironmental Engineering., Vol. 136 No. 4, pp. 573-582.

[3]. Roy S., Chattapadhyay B. and Sahu R. (2013), "Pile Behaviour Under Inclined Compressive Loads-A Model Study", Electronics Journal of Geotechnical Engineering, Vol. 18, pp. 2187-2205.

[4]. Su, D., and Zhou, Y. G. (2015), "Effect of Loading Direction on the Response of Laterally Loaded Pile Groups in Sand." International Journal of Geomechanics, Vol. 16. pp. 1-12. 


\section{BIOGRAPHIES}

Dr. Sunil Shaligram Pusadkar completed $\mathrm{Ph}$. D. (2005) from IIT Roorkee. He posses 26 years of industrial and teaching experience. He guided $16 \mathrm{~B}$. Tech projects and $13 \mathrm{M}$. Tech dissertation. He published 13 research papers in international journals, 2 paper in national journal and 40 in national and international conferences. He is registered guide for Ph. D. in Sant Gadge Baba Amravati University, Amravati. He had completed two AICTE sponsored projects. He had filed one patent also

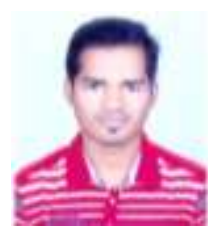

Mukesh A. Kapse, He passed B. E. (Civil Engineering). Now he is pursuing M. Tech. (Geotechnical Engineering) at Department of Civil Engineering, Govt. College of Engg. Amravat 